Primljen / Received: 18.9.2015. Ispravljen / Corrected: 22.6.2016.

Prihvaćen / Accepted: 22.9.2016.

Dostupno online / Available online: 10.3.2017.

\title{
Strength properties of slag/fly ash blends activated with sodium metasilicate
}

\section{Authors:}

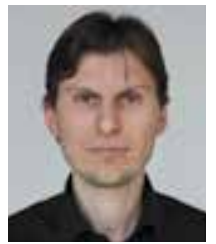

${ }^{1}$ Assist.Prof. Erion Luga, PhD. CE eluga@epoka.edu.al

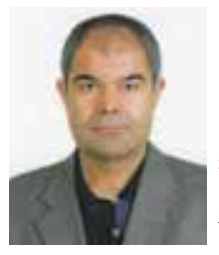

2Prof. Cengiz Duran Atis, PhD. CE cdatis@erciyes.edu.tr

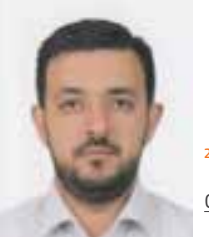

${ }^{2}$ Assoc.Prof.OkanKarahan,PhD.CE okarahan@erciyes.edu.tr

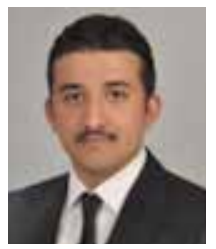

Serhan Ilkentapar, MSc.CE serhan@erciyes.edu.tr

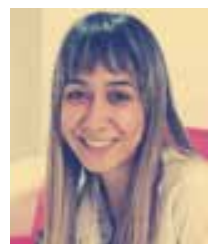

${ }^{3}$ AssistProf.ElaBahsudeGorur,PhD.CE elagorur@ksu.edu.tr

'EPOKA University, Tirana, Albania ERCiYES University, Kayseri, Turkey ${ }^{3}$ Kahramanmaraş Sütçü İmam University, Kahramanmaraş, Turkey

\section{Erion Luga, Cengiz Duran Atis, Okan Karahan, Serhan Ilkentapar, Ela Bahsude Gorur \\ Strength properties of slag/fly ash blends activated with sodium metasilicate}

The alkali activation of mortar blends containing Ground Granulated Blast Furnace Slag and Fly Ash, with activation based on sodium metasilicate, is investigated in this study. Two series are investigated, and compressive strength is measured. The results of the first series show that the compressive strength decreases considerably with a decrease in the slag and fly ash ratio. The 3-day compressive strength of mortar cured at the temperature of $100^{\circ} \mathrm{C}$ increases slightly up to the ratio of $60 / 40$, but decreases considerably at the $40 / 60$ ratio.

Key words:

ground-granulated blast furnace slag, fly ash, geopolymer, sodium metasilicate

Prethodno priopćenje

Erion Luga, Cengiz Duran Atis, Okan Karahan, Serhan Ilkentapar, Ela Bahsude Gorur

\section{Svojstva čvrstoće mješavina zgure/letećeg pepela aktiviranih pomoću} natrijevog metasilikata

U radu se analizira alkalno aktiviranje mješavina morta koje sadrže mljevenu granuliranu zguru iz visokih peći i leteći pepeo, pri čemu se aktivacija odvija pomoću natrijevog metasilikata. Analiziraju se dvije serije te je izmjerena tlačna čvrstoća. Rezultati dobiveni za prvu seriju pokazuju da se tlačna čvrstoća bitno smanjuje sa smanjenjem omjera zgure i letećeg pepela. Trodnevna tlačna čvrstoća morta njegovanog pri temperaturi $100{ }^{\circ} \mathrm{C}$ donekle se povećava do omjera 60/40, ali se bitno smanjuje pri omjeru 40/60.

Ključne riječi:

mljevena granulirana zgura iz visokih peći, leteći pepeo, geopolimer, natrijev metasilikat

Vorherige Mitteilung

Erion Luga, Cengiz Duran Atis, Okan Karahan, Serhan Ilkentapar, Ela Bahsude Gorur

\section{Eigenschaften der Festigkeit durch Natriummetasilikat aktivierter Mischungen aus Schlacke/Flugasche}

In dieser Arbeit wird die Alkali-Aktivierung von Mörtelmischungen mit gemahlener granulierter Hochofenschlacke und Flugasche analysiert, wobei die Aktivierung durch Natriummetasilikat erzielt wird. Es werden zwei Serien analysiert und Werte der Druckfestigkeit gemessen. Die Resultate der ersten Serie zeigen, dass die Druckfestigkeit bei einem kleineren Verhältnis von Schlacke und Flugasche deutlich sinkt. Die dreitägige Druckfestigkeit bei einer Temperatur von $100{ }^{\circ} \mathrm{C}$ gepflegten Mörtels steigt zwar ansatzweise bis zu einem Verhältnis von 60/40, sinkt aber stark bei einem Verhältnis von 40/60.

Schlüsselwörter

gemahlene granulierte Hochofenschlacke, Flugasche, Geopolymer, Natriummetasilikat 


\section{Introduction}

Concrete is nowadays the most extensively used and the most important material in the construction sector. Its production is estimated to exceed 10 billion tons per year [1]. Technological developments and the rise in demand for ordinary Portland cement concrete has made Portland cement the most widely used commodity in the construction industry [2]. It is reported that cement production has a very negative impact on the environment. Cement industry produces more than $7 \%$ of the $\mathrm{CO}_{2}$ released in the environment, i.e. approximately one tone of carbon dioxide for every tone of cement produced [1]. Also, large amounts of natural resources and nearly 2-3\% of global primary energy is needed during this process [3].

On the other hand, slag and fly-ash storage constitutes a significant environmental problem [4]. Ground Granulated Blast Furnace Slag is a by-product obtained in the manufacture of pig iron in the blast furnace. It is produced from the combination of earthy constituents during iron-ore melting in blast furnaces in the presence of limestone as flux. When the molten slag is quickly cooled it turns into a fine, granular, almost fully non-crystalline, glassy form known as granulated slag. When the granulated slag is finely ground and combined with Portland cement, it exhibits very good cementing properties [5].

Fly Ash is released by factories and thermal power plants and its amount has been increasing considerably. The disposal of fly ash has become a serious environmental and economic problem. Previously, fly ash was generally released into the atmosphere but, according to current pollution control measures, it should be captured prior to release [6]. Alkali activation of these waste materials has emerged as an attractive alternative to conventional binders [7]. Known also as geopolymers these binders are produced as a result of reaction of materials that contain both alumina and silica with alkaline solutions, forming an aluminosilicate structure [8].

Davidovits stresses out great importance of the development of alternative binders produced from mineral admixtures such as fly ash, silica fume, ground granulated blast furnace slag, rice husk ash, and metakaolin. For this purpose, he strongly suggests improvement of geopolymer technology as an alternative to Portland cement [9].

Concretes produced by activation of the ground granulated blast-furnace slag with an alkaline solution are called alkali activated slag concretes. Instead of using Portland cement as a binder, they are obtained by using only alkali activated ground granulated blast furnace slag [10].

Researchers from different parts of the world have been analysing for more than fifty years different types of raw materials and activators, as well as geopolymer activation possibilities. At the same time, they have been trying to determine properties of these innovative materials.

In this context, Atis \& Bilim investigated the alkali activation of geopolymers produced by replacing Portland cement with the ground granulated blast furnace slag in different proportions. They used sodium silicate as activator and measured the carbonation, compressive strength, and flexural strength of the mortars. Thus they concluded that the mortars produced by $100 \%$ alkali activated ground granulated blast furnace slag as a binder showed better properties than the blended ones [11]. Studies also show that the ground granulated blast furnace slag can be activated with alkalis such as sodium hydroxide $(\mathrm{NaOH})$, sodium carbonate $\left(\mathrm{Na}_{2} \mathrm{CO}_{3}\right)$, and water glass $\left(\mathrm{Na}_{2} \mathrm{SiO}_{3}\right)$. The hydration of the alkali-activated ground granulated blast furnace slag is similar to the hydration process of normal Portland cement and, in the end, hydration products similar to $\mathrm{C}-\mathrm{S}-\mathrm{H}$ are formed. The activation energy is nearly $57.6 \mathrm{~kJ} /$ mol. Some non-continuous micro cracks can be distinguished in the inner structure of the alkali activated ground granulated blast furnace slag concrete, which is of great importance with regard to permeability. In this context, studies regarding the crack formation mechanism model are continuously being made $[12,13]$.

Research shows that activator modules and concentrations are highly significant in the alkali activation of the ground granulated blast furnace slag. Bakharev et al. report that, for the same water to binder ratio, the mortars produced by activation of the ground granulated blast furnace slag with sodium silicate demonstrated higher strength than those produced with Portland cement. On the other hand, high silica modules of the activator decreased the early strength and setting time, whereas high concentration of alkaline increased shrinkage values of geopolymer mortars [14].

Fly ash has also been widely investigated with regard to production of geopolymers. Xie \& Xi investigated hardening mechanism of the alkali-activated low calcium fly ash mortars. After curing the water-glass activated fly ash mortars for 24 hours at $60^{\circ} \mathrm{C}$, they observed the beginning of hardening of amorphous or low crystalline order $\mathrm{Na}_{2} \mathrm{O}-\mathrm{Al}_{2} \mathrm{O}_{3}$ $\mathrm{SiO}_{2}$ formations [15].

Olivia \& Nikraz worked on the compressive strength evolution, water absorption and water permeability of the low-calcium fly ash geopolymer concrete. They reported that good quality geopolymer concrete can be produced by activating lowcalcium fly ash in proper mix proportions [16]. Tho-in et al. investigated the properties of high calcium fly ash geopolymer binders. They concluded that high calcium fly ash geopolymer concretes possess satisfactory mechanical properties and the density, porosity and compressive strength values that are similar to the ones exhibited by conventional concretes [17]. Curing conditions during the alkali-activated fly ash setting period play a very important role in the evolution of mechanical and microstructural properties. Kovalchuk et al. produced a $102 \mathrm{MPa}$ compressive strength geopolymer concrete by curing it for 8 hours at $95^{\circ} \mathrm{C}$ in a covered mould [7].

Atis et al. investigated mechanical properties of alkaliactivated fly ash geopolymer mortars, by activating Class $\mathrm{F}$ fly ash with $\mathrm{NaOH}$ in different $\mathrm{Na}$ concentrations, at curing 
temperatures from 45 to $115^{\circ} \mathrm{C}$. As a result, they obtained very high compressive strength and flexural tensile strength values of up to 120 and $15 \mathrm{MPa}$, respectively [18].

The alkali activation of blended slag/fly ash has also been in the focus of a number of studies. Shi \& Day studied the hydration and strength development of activated mortars made of $50 \%$ slag and $50 \%$ fly ash activated with sodium hydroxide and sodium silicate for both classes of fly ash. They reported that the type of fly ash does not have a great effect, and that sodium silicate increases the strength, whereas the maximum strength is obtained from slag mortars activated with $\mathrm{Na}_{2} \mathrm{SiO}_{3}$ [19].

Puertas et al. investigated strength development and hydration products of fly ash/slag geopolymers activated with $2 \mathrm{M}$ and $10 \mathrm{M} \mathrm{NaOH}$ solution cured at $25^{\circ} \mathrm{C}$ and $65^{\circ} \mathrm{C}$. According to their results, the fly ash/slag ratio and activator concentration are the most important factors for strength development, whereas the curing temperature exhibits lesser effects compared to the previous two factors [4].

Zhao et al. reported that the fly ash/slag ratio plays an important role in the strength properties of alkali activated fly ash/slag mortars. When fly ash is used in right proportions, it can decrease the cost without affecting the strength [20]. Blended slag/fly ash binders are attracting the attention of many researchers as a way of producing new geopolymer binders. In this context, many studies are being conducted in order to get a clearer idea about their coexistence in the same binding system, and to find an optimum ratio between these two components [21].

The effect of slag and fly ash ratio on the strength properties and strength development of the normally cured and heat cured slag/fly ash blends activated with sodium metasilicate have been investigated in this study.

\section{Properties of materials}

\section{Ground granulated blast-furnace slag (GGBFS)}

The GGBFS was provided from the Iskenderun Iron-Steel Factory located in southern Turkey. Its chemical composition is given in Table 1 . The specific gravity of GBFS was $2.81 \mathrm{~g} / \mathrm{cm}^{3}$. The blast furnace slag was ground granulated in Iskenderun Cement Factory so as to obtain a Blaine specific surface area of about $4250 \mathrm{~cm}^{2} / g$. According to ASTM C989 [22] hydraulic activity index, the GGBFS used was classified as the grade 80 slag.

\section{Fly ash (FA)}

Class F fly ash originating from Sugozu Thermal Power Plant situated in Yumurtalık-Adana district in southern Turkey was used in the study. The chemical properties of fly ash are given in Table 1. According to standard limits presented in EN 4501 [23] and ASTM C618-94a [24], the value of $\mathrm{SiO}_{2}+\mathrm{Al}_{2} \mathrm{O}_{3}+$ $\mathrm{Fe}_{2} \mathrm{O}_{3}$ exceeds $70 \%$ and, its $\mathrm{CaO}$ content is less than $10 \%$. Consequently the current FA is classified as class $\mathrm{F}$ (low lime) fly ash. The specific gravity of the FA used is $2.39 \mathrm{~g} / \mathrm{cm}^{3}$, and the Blaine specific surface area is $2900 \mathrm{~cm}^{2} / \mathrm{g}$. The pozzolanic strength activity index determined according to ASTM C 618 [24] was 78 at 28 days.

Table 1. Chemical composition of GGBFS and FA (\%)

\begin{tabular}{|c|c|c|c|c|c|c|c|c|c|}
\hline Oxide & $\mathrm{SiO}_{2}$ & $\mathrm{Al}_{2} \mathrm{O}_{3}$ & $\mathrm{Fe}_{2} \mathrm{O}_{3}$ & $\mathrm{CaO}$ & $\mathrm{MgO}$ & $\mathbf{S O}_{3}$ & $\mathrm{~K}_{2} \mathbf{O}$ & $\mathrm{Na}_{2} \mathbf{O}$ & LOI \\
\hline GGBFS & 36,7 & 5,20 & 0,98 & 32,61 & 10,12 & 0,99 & 0,76 & 0,42 & 2,88 \\
\hline FA & 61,81 & 19,54 & 7,01 & 1,77 & 2,56 & 0,31 & 0,99 & 2,43 & 2,20 \\
\hline
\end{tabular}

\section{Alkali activator}

The sodium metasilicate used in this study as an alkali activator for the activation of the ground granulated blast furnace slag and the fly ash was provided by Silmaco Silicates. The modulus of sodium metasilicate $\mathrm{SiO}_{2} / \mathrm{Na}_{2} \mathrm{O}$ is equal to 1 .

\section{Sand}

Rilem-Cembureau Standart sand was used for the preparation of the mortar specimens. The grading of the sand is given in Table 2 .

Table 2. The Grading of Standard CEN Sand

\begin{tabular}{|l|l|l|l|l|l|l|}
\hline Sieve size $[\mathrm{mm}]$ & 2 & 1,6 & 1 & 0,5 & 0,16 & 0,08 \\
\hline Cumulative percentage & 0 & 7 & 33 & 67 & 87 & 99 \\
\hline
\end{tabular}

\section{Experimental work}

\subsection{Preparation of specimen mixtures}

Blended slag and fly ash alkali activated mortars were investigated in this study. The RILEM sand, GGBFS and/or FA, water, and sodium meta-silicate, were used in in the production of these mortars, in conformity with TS-EN196-1 [25]. The water to binder ratio is a well-known factor that affects mortar properties. In order to fix the effect of the water to binder ratio, and as the effect of the water to binder ratio on the properties of Slag/Fly Ash Blends activated with Sodium Metasilicate mortars was not an objective of this research, it has not been considered as a factor in the experimental design. Thus, the constant value of 0.5 was adopted for the water/binder ratio in accordance with TS-EN196-1 [25]. The amount of the binder GGBFS+FA was also kept constant at $450 \mathrm{~g}$, in conformity with the same standard. The mortars were cured at different temperatures in two different series. Na amount (6\% of GGBFS+FA) was kept constant for all mixtures. The $6 \%$ value is taken from literature since it provided an appropriate compressive strength [26-28]. In their research, Bilim et al. and Atis et al. explained that they reached optimum results with mixes prepared at a molar ratio equal to 1 . They also stressed that although the $6 \% \mathrm{Na}$ ratio is not an optimum value from the performance point of view, it is quite optimal from the strength/cost aspect $[27,28]$. The $6 \% \mathrm{Na}$ ratio is converted to approximately $8 \%$ of $\mathrm{Na}_{2} \mathrm{O}$ to solid phase 
ratio, and it was accepted as an appropriate ratio for this study. In the first normal-cured (NC) series, specimens were cured at 95 $\%$ humidity at room temperature, whereas in the second heatcured $(\mathrm{HC})$ series, the specimens were dry-cured at $100^{\circ} \mathrm{C}$. The design of the mixtures was simplified by replacing $20 \%$ GGBFS (by weight) with FA in order to reach an optimum ratio for each of the curing conditions. The ingredients of the mortar mixtures are given in Table 3. As a highly sophisticated apparatus and autoclave system needed for closed curing (with prevention of water loss) at elevated temperature was unavailable, an economical curing method (in oven at $100^{\circ} \mathrm{C}$ ) was selected in this study for alkali activation.

Table 3. Mortar mixture ingredients

\begin{tabular}{|c|c|c|c|c|c|}
\hline $\begin{array}{c}\text { Mixture } \\
\text { number }\end{array}$ & $\begin{array}{c}\text { Ratio of } \\
\text { water to } \\
\text { binder }\end{array}$ & $\begin{array}{c}\text { Binder } \\
{[\mathrm{g}]}\end{array}$ & $\begin{array}{c}\text { GGBFS } \\
{[\%]}\end{array}$ & $\begin{array}{c}\text { FA } \\
{[\%]}\end{array}$ & Sand $[\mathrm{g}]$ \\
\hline $\mathbf{1}$ & 0.5 & 450 & 100 & 0 & 1350 \\
\hline $\mathbf{2}$ & 0.5 & 450 & 80 & 20 & 1350 \\
\hline $\mathbf{3}$ & 0.5 & 450 & 60 & 40 & 1350 \\
\hline $\mathbf{4}$ & 0.5 & 450 & 40 & 60 & 1350 \\
\hline $\mathbf{5}$ & 0.5 & 450 & 20 & 80 & 1350 \\
\hline $\mathbf{6}$ & 0.5 & 450 & 0 & 100 & 1350 \\
\hline
\end{tabular}

\subsection{Casting of specimens}

The mixes were prepared according to mix proportions given in Table 3. This was followed by mixing in the Hobart mixer in a predefined order. The Hobart mixer operates at 140 and 285 rotations/minute in conformity with TS-EN196-1 [25]. By means of an electronic device its operation can be fully automated. The Hobart mixer was used in automatic mode according to TS-EN196-1 [25]. First, the water and sodium metasilicate were mixed in a glass jar until full dissolution in order to obtain a more homogeneous mix enabling easier $\mathrm{SiO}_{2}$ and $\mathrm{NaO}_{2}$ dispersion within the mortar. After that, the solution and $450 \mathrm{~g}$ of binder were put in the mixer operating in low gear for 30 seconds. In the second step, while the mixer was still working, the sand was added slowly and mixed for 30 seconds again in low gear. In the third step, the mixer suddenly shifted in high gear and the mixing continued for 30 additional seconds. In the fourth step, the mixing was stopped for 15 seconds. After that the mixing resumed for 60 seconds in high gear. The specimens were cast into prismatic moulds measuring $40 \times 40 \times 160 \mathrm{~mm}$. As the mixer stopped, the fresh mortar was placed with an appropriate spoon into the moulds in two layers and shaken in the jolting apparatus, where it was impacted 60 times in one minute. Then the mortar surface was finished. The specimens of the first series were taken out of the moulds after 24 hours and cured for 3 , 7 and 28 days in water at $21 \pm 1^{\circ} \mathrm{C}$, whereas the specimens of the second series were put into the oven immediately after being placed into moulds. There they were cured in dry conditions for 24,48 and 72 hours at $100^{\circ} \mathrm{C}$. After each curing period the specimens were tested to measure their compressive strength.

\subsection{Determination of compressive strength}

The compressive strength of specimens was tested according to TS-EN196-1 [25]. The $40 \times 40 \times 160 \mathrm{~mm}$ sized specimens were used in the compressive strength testing. The loading rate was 500 N/s. The loading area was $40 \times 40$ mm. Figure 1 shows the testing machine and apparatus used for the compressive strength testing of some of the specimens. The colour of the specimens becomes darker as the fly ash percentage increases.

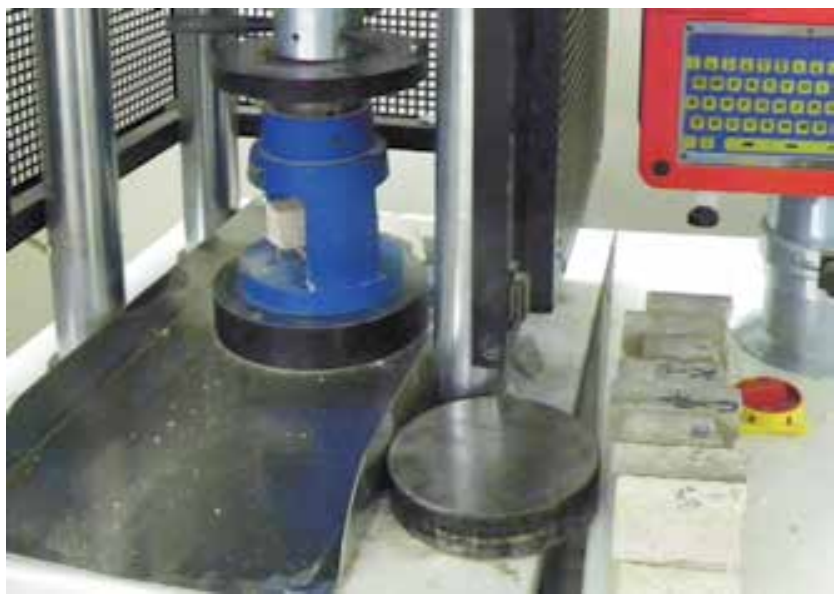

Figure 1. Compressive strength test

\section{Results and discussion}

Test results presented in Figure 1 show evolution of compressive strength for the mortars cured at room temperature. It can be seen for the graph showing mortar properties at 3, 7 and 28 days (Figure 2) that the compressive strength decreases as the slag and fly ash ratio decreases. This shows that the slag and fly ash ratio is a very important factor in the activation of slag and fly ash blend mortars [4].

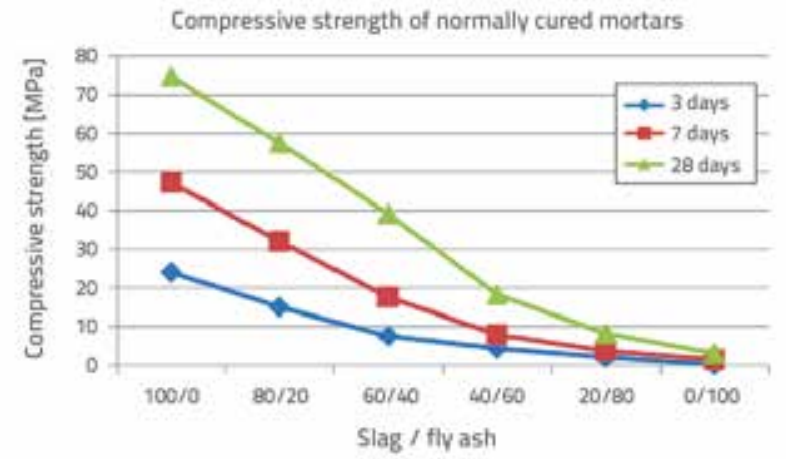

Figure 2. Evolution of compressive strength according to slag/fly ash ratio for normal curing 
Table 4. Oxide percentages for each slag and fly ash ratio

\begin{tabular}{|c|c|c|c|c|c|c|c|c|c|}
\hline $\begin{array}{l}\text { Slag / } \\
\text { fly ash }\end{array}$ & $\mathrm{SiO}_{2}$ & $\mathrm{Al}_{2} \mathrm{O}_{3}$ & $\mathrm{CaO}$ & $\mathrm{Na}_{2} \mathrm{O}$ & $\mathrm{SiO}_{2} / \mathrm{Al}_{2} \mathrm{O}_{3}$ & $\mathrm{CaO} / \mathrm{SiO}_{2}$ & $\mathrm{CaO} / \mathrm{SiO}_{2}+\mathrm{Al}_{2} \mathrm{O}_{3}$ & $\begin{array}{c}28 \text { days NC } \\
{[\mathrm{MPa}]}\end{array}$ & $\begin{array}{c}72 \text { days HC } \\
\text { [MPa] }\end{array}$ \\
\hline $100 / 0$ & 36,7 & 5,2 & 32,6 & 0,42 & 7,1 & 0,89 & 0,78 & 74,8 & 42,7 \\
\hline $80 / 20$ & 41,7 & 8,1 & 26,4 & 0,82 & 5,2 & 0,63 & 0,53 & 57,6 & 45,7 \\
\hline $60 / 40$ & 46,7 & 10,9 & 20,3 & 1,22 & 4,3 & 0,43 & 0,35 & 39,3 & 46,6 \\
\hline $40 / 60$ & 51,8 & 13,8 & 14,1 & 1,63 & 3,8 & 0,27 & 0,22 & 18,2 & 12,1 \\
\hline $20 / 80$ & 56,8 & 16,7 & 7,9 & 2,03 & 3,4 & 0,14 & 0,11 & 8,4 & 13,7 \\
\hline \multirow[t]{3}{*}{$0 / 100$} & 61,8 & 19,5 & 1,77 & 2,43 & 3,2 & 0,03 & 0,02 & 3,1 & 15,4 \\
\hline & & & 0,9665 & & 0,9206 & 0,9879 & 0,9844 & $\mathbf{R}^{2}$ & \\
\hline & & & 0,688 & & 0,5163 & 0,6552 & 0,6367 & & $\mathbf{R}^{2}$ \\
\hline
\end{tabular}

The mortars produced with $100 \%$ fly ash show a very low level of activation. After 28 days of curing at room temperature, the highest compressive strength value was $74.8 \mathrm{MPa}$ for NC1, produced with a $100 / 0$ slag to fly ash ratio.

The evolution of compressive strength of alkali activated mortars cured at room temperature according to curing age was analysed. The compressive strength values of all mortars increase with the age of curing. However, the slope and values are higher when the slag to fly ash ratio is higher. Geopolymeric reaction of fly ash at room temperature is low. On the other hand, test results show that the GGBFS can be activated at room temperature by alkali medium [19]. Previous research shows similar results about alkali activated Class $F$ fly ash systems. The activation reactions do not proceed at the rate that is sufficient to produce high strength paste under ambient temperature. Elevated temperatures are necessary to accelerate the reactions [15].

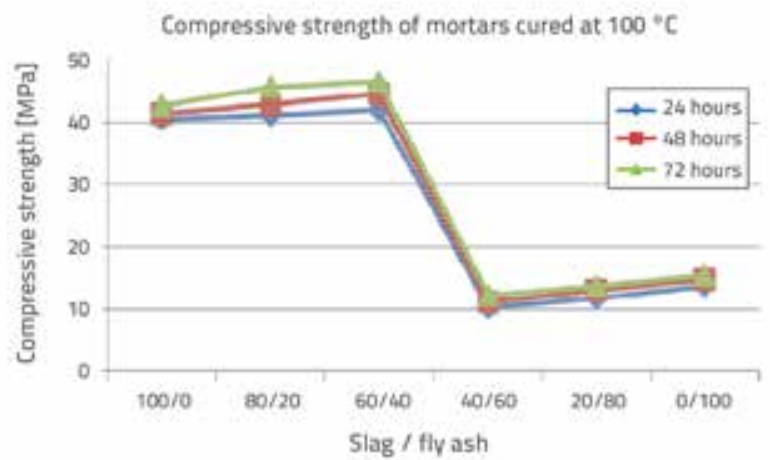

Figure 3. Effect of heat curing duration on compressive strength according to slag/fly ash ratio for heat curing

Test results presented in Figure 3 show the effect of heat curing duration on of the compressive strength of mortars dry-cured at $100^{\circ} \mathrm{C}$. The graph showing heat-cured mortar properties at 24 , 48 and 72 hours indicates that the compressive strength trend related to the slag and fly ash ratio is very different from that of the specimens cured at room temperature. Nevertheless, it can be seen that the slag and fly ash ratio is a very important factor regarding compressive strength values of mortars. When the amount of fly ash exceeds $60 \%$ in the fly ash-slag blend, the compressive strength is affected drastically and it value drops. As can be seen in this graph, compressive strength values of each slag and fly ash ratio do not increase much after the first 24 hours, which shows that in this case the period of 24 hours is sufficient for curing.

The graph presented in Figure 3 shows that compressive strength values change in a narrow range of 40.5 to $46.6 \mathrm{MPa}$ when the slag and fly ash ratio is equal to or greater than 60/40. As the slag and fly ash ratio falls below 40/60, compressive strength values of all mortars decrease drastically, but remain close to each other and vary between 10.2 and 15.4MPa.

Research shows that two different types of gel structures form in activated slag and fly ash: $\mathrm{C}-\mathrm{A}-\mathrm{S}-\mathrm{H}$, which is mainly formed of the alkali activated slag, and $\mathrm{N}-\mathrm{A}-\mathrm{S}-\mathrm{H}$, which is mainly formed in fly ash systems [29].

An increase in FA content in the mixture has a beneficial influence on the compressive strength up to 60/40 slag and fly ash ratio for the heat curing $(\mathrm{HC})$ condition. However, it has a detrimental effect if the amount of fly ash exceeds $60 \%$ in the slag-fly ash blend for both curing condition (NC and HC) [20]. This happens because alkali activated fly ash systems require higher activator concentrations [18].

When comparing maximum compressive strength values reached for each of the two curing conditions, the normal curing specimens reach higher values than the heat cured ones in the end of the respective curing period. This situation is related to the evaporation of water needed for the hydration process of the paste and, as a result, the reaction is completed within 24 hours.

Table 4 shows the change in some of the most important oxide percentages according to slag and fly ash ratio, as well as the change in the ratios of these oxides. The last two columns refer to respective average compressive strength values for each slag and fly ash ratio in both curing methods. The above correlations 

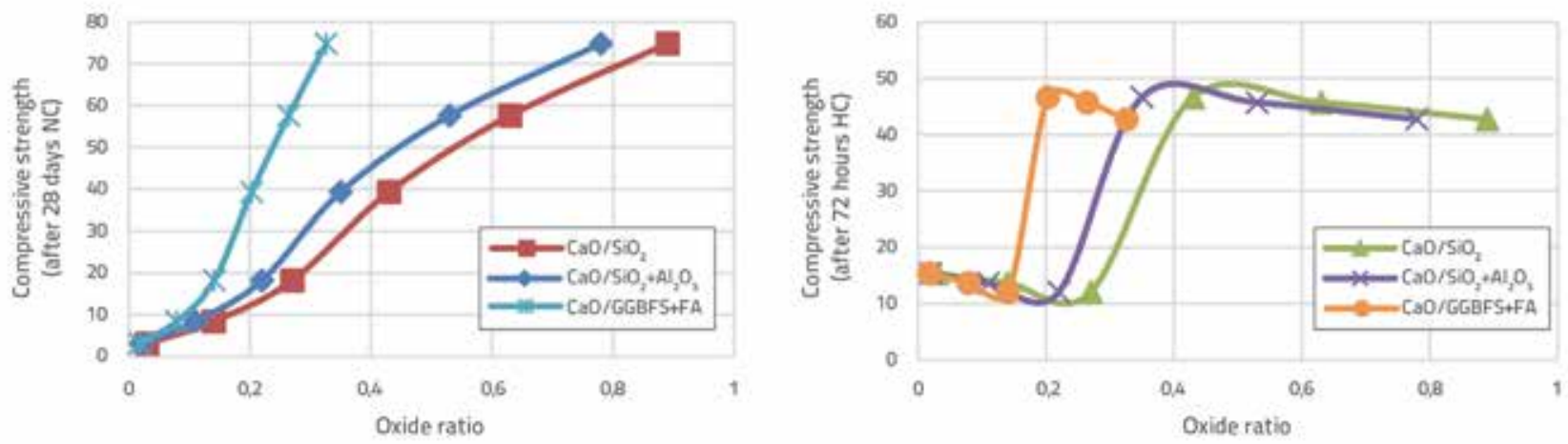

Figure 4. Relationship between oxide ratios and compressive strength for NC (normal-cured) and HC (heat-cured) specimens

are obtained when the oxide content of the blend is compared to the compressive strength values for both curing methods. It can be seen that the strength development of Normal Cured mortars is strongly correlated to the $\mathrm{CaO}$ content [30] and its ratio to $\mathrm{SiO}_{2}$ and $\mathrm{Al}_{2} \mathrm{O}_{3}$. However, such a correlation was not observed in Heat Cured mortars because of the temperature factor.

Figure 4 also illustrates the relationship between the ratio of some of the main oxides to each other (such as $\mathrm{CaO} / \mathrm{SiO} 2, \mathrm{CaO} /$ $\mathrm{SiO} 2+\mathrm{Al} 2 \mathrm{O3}$ ) and the total blend $\mathrm{CaO} / \mathrm{GGBFS}+\mathrm{FA}$ for each slag to fly ash ratio, including also compressive strength values of specimens for both curing methods. The first graph shows the relationship of the oxide ratios to the 28-day compressive strength of specimens cured in normal conditions, whereas the second graph shows the relationship of the oxide ratios to the 72-hour compressive strength of specimens cured at $100^{\circ} \mathrm{C}$. Both graphs are visual representations of data given in Table 4.

\section{Conclusions}

The alkali activation of slag and fly ash blend mortars activated with sodium metasilicate is analysed in this study. According to test results, the following conclusion can be made:
- The slag and fly ash is a very important factor in the alkali activation process of Slag and fly ash blend mortars activated with sodium metasilicate.

- The compressive strength of alkali-activated mortars cured at room temperature steadily decreases with an increase in the fly ash content.

- The high strength geopolymeric mortar with the compressive strength in the order of $75 \mathrm{MPa}$ at 28 days can be obtained by activating slag and fly ash blend with sodium metasilicate cured at room temperature.

- For a geopolymer mixture, the compressive strength increases slightly with an increase in heat curing time, when compared to short curing time. Nevertheless, $40 \mathrm{MPa}$ compressive strength can be obtained from the 100/0, $80 / 20$ and $60 / 40$ slag and fly ash blend mortars cured for 24 hours at $100^{\circ} \mathrm{C}$.

- The use of $40 \%$ Fly Ash in the slag and fly ash blend mortars cured at $100^{\circ} \mathrm{C}$ is found to be beneficial by decreasing the cost without decreasing the strength of the mortars. NC4,5,6 and HC4,5,6 can be used for the production of masonry blocks.

- The use of the slag and fly ash in the same binding medium is not very beneficial.

- For activated slag mortars, normal curing is more appropriate than heat curing.

\section{REFERENCES}

[1] Meyer, C.: The Greening Of The Concrete Industry, Cement, Concrete Composites, 31 (2009), pp. 601-605, https://doi. org/10.1016/j.cemconcomp.2008.12.010

[2] Criado, M., Palomo, A., Fernandes-Jimenez, A.: Alkali Activation Of Fly Ashes. Part 1: Effect Of Curing Conditions On The Carbonation Of The Reaction Products, FUEL, 84 (2005), pp. 2048-2054, https://doi.org/10.1016/j.fuel.2005.03.030

[3] Juenger, M., Winnefeld, F., Provis, J., Ideker, J.: Advances In Alternative Cementitious Binders, Cement, Concrete Research, 41 (2011), pp. 1232-1243, https://doi.org/10.1016/j. cemconres.2010.11.012
[4] Puertas, F., Martinez-Ramirez, S., Alonso, S., Vazquez T.: AlkaliActivated Fly Ash/Slag Cement Strength Behaviour, Hydration Products, Cement, Concrete Research, 30 (2000), pp. 1625-1632, https://doi.org/10.1016/S0008-8846(00)00298-2

[5] Erdoğan, T.Y.: Admixtures for Concrete, Ankara: METU Press Publishing Company, 1997.

[6] Al-Zboona, K., Al-Harahshehb, M.S., Hania, F.B.: Fly ash-based geopolymer for $\mathrm{Pb}$ removal from aqueous solution, Journal of Hazardous Materials, 188 (2011), pp. 414-421, https://doi. org/10.1016/j.jhazmat.2011.01.133 
[7] Kovalchuk, G., Fernandez-Jimenez, A., Palomo, A.: Review, Alkali-Aktivated Fly Ash: Effect Of Thermal Curing Conditions On Mechanical, Microstructural Development-Part II, FUEL, 86 (2007), pp. 315-322, https://doi.org/10.1016/j.fuel.2006.07.010

[8] Wongpa, J., Kiattikomol, K., Jaturapitakkul, C., Chindaprasirt, P.: Compresive Strength, Modulus Of Elasticity, Water Permeability, Of Inorganic Polyper Concrete,: Materials, Design, 31 (2010), pp. 4748-4754, https://doi.org/10.1016/j.matdes.2010.05.012

[9] Davidovits, J.: High-Alkali Cements For $21^{\text {st }}$ Century Concretes. In Concrete Technology, Past, Present, Future, Metha, P.K., Ed., in V. Mohan Malhotra Symposium, Detroid, 1994.

[10] Collins, F., Sanjayan, J.: Microcracking, Strength Development of Alkali Activated Slag Concrete, Cement, Concrete Composites, 23 (2001), pp. 345-352, https://doi.org/10.1016/S09589465(01)00003-8

[11] Bilim, C., Atiș, C.D.: Alkali Activation Of Mortars Containing Different Replacement Levels Of Ground Granulated Blast Furnace Slag, Construction, Building Materials, 28 (2012), pp. 708-712, https:// doi.org/10.1016/j.conbuildmat.2011.10.018

[12] Zhou, Z., Wu, X., Xu, Z., Tang, M.: Kinetic Study on Hydration of Alkali-Activated Slag, Cement, Concrete Research, 23 (1993), pp. 1253-1258, https://doi.org/10.1016/0008-8846(93)90062-E

[13] Collins, F., Sanjayan, J.G.: Effect of Pore Size Distribution on Drying Shrinkage of Alkai Activated Slag Concrete, Cement, Concrete Research, 30 (2000), pp. 1401-1406, https://doi.org/10.1016/ S0008-8846(00)00327-6

[14] Bakharev, T., Sanjayan, J.G., Cheng, Y.B.: Alkali Activation of Australian Slag Cements, Cement, Concrete Research, 29 (1999), pp. 113-120, https://doi.org/10.1016/S0008-8846(98)00170-7

[15] Xie, Z., Xi, Y.: Hardening Mechanisms Of An Alkaline-Activated Class F Fly Ash, Cement, Concrete Research, 31 (2001), pp. 12451249, https://doi.org/10.1016/S0008-8846(01)00571-3

[16] Olivia, M., Nikraz, H.R.: Strength, Water Penetrabillity of Fly Ash, ARPN Journal of Engineering, Applied Sciences, 6 (2011), pp. 70-78.

[17] Tho-in, T., Sata, V., Chindaprasirt, P., Jaturapitakkul, C.: Pervious High-Calcium Fly Ash Geopolymer Concrete, Construction, Building Materials, 30 (2012), pp. 366-371, https://doi.org/10.1016/j. conbuildmat.2011.12.028

[18] Atis, C., Görür, E., Karahan, O., Bilim, C., Ilkentapar, S., Luga, E.: Very High Strength (120 MPa) Class F Fly Ash Geopolymer Mortar Activated At Different $\mathrm{NaOH}$ Amount, Heat Curing Temperature, Heat Curing Duration, Construction, Building Materials, 96 (2015), pp. 673-678, https://doi.org/10.1016/j.conbuildmat.2015.08.089
[19] Shi, C., Day, R.L.: Early Strength Development, Hydration of Blast Furnace Slag/Fly Ash Blends, Advances in Cement Research, 11 (1999), pp. 189-196, https://doi.org/10.1680/adcr.1999.11.4.189

[20] Zhao, F.Q., Ni, W, Wang, H.J., Liu, H.J.: Activated Fly Ash/Slag Blended Cement, Resources ConservationiRecycling, 52 (2007), pp. 303-313, https://doi.org/10.1016/j.resconrec.2007.04.002.

[21] Provis, J.L., Myers, R.J., White, C.E., Rose, V., Deventer, J.S.: X-Ray Microtomography Shows Pore Structure, Tortuosity In AlkaliActivated Binders, Cement, Concrete Research, 42 (2012), pp. 855-864, https://doi.org/10.1016/j.cemconres.2012.03.004

[22] ASTM-C989: Standard Specification for Slag Cement for Use in Concrete, Mortars, Pennsylvania: Annual Book of ASTM Standards, 2014.

[23] EN450-1: Fly Ash For Concrete - Part 1: Definitions, Specifications, Conformity Criteria, Brussels: European Committee for Standartization, 2012.

[24] ASTM-C618-94a: Standard Specification for Coal, Fly Ash, Raw or Calcined Natural Pozzolan for Use as a Mineral Admixture in Portland Cement Concrete, Annual Book of ASTM Standards, V. 04.02, Concrete, Aggregates ", Philadelphia: American Society for Testing, Materials, 1997

[25] TS-EN196-1: Methods of Testing Cement - Part 1: Strength Determination, Ankara: TSE-Turkish Standards Institution, 2009.

[26] Al-Otaibi, S.: Durability Of Concrete Incorporating GGBS Activated By Water-Glass, Construction, Building Materials, 22 (2008), pp. 2059-2067, https://doi.org/10.1016/j.conbuildmat.2007.07.023

[27] Bilim, C., Karahan, O., Atis, C.D., Ilkentapar, S.: Effects of chemical admixtures, curing conditions on some properties of alkali-activated cementless slag mixtures, KSCE Journal Of Civil Engineering, 19 (2015), pp. 733-741, https://doi.org/10.1007/ s12205-015-0629-0

[28] Atis, C.D., Bilim, C., Celik, O., Karahan, O.: Influence of activator on the strength, drying shrinkage of alkali-activated slag mortar, Construction, Building Materials, 23 (2009), pp. 548-555, https:// doi.org/10.1016/j.conbuildmat.2007.10.011

[29] Bernal, S.A., Provis, J.L., Walklay, B., San Nicolas, R., Gehman, J.D., Brice, D.G., Kilcullen, A.R., Duxson, P., van Deventer, J.S.J.: Gel nanostructure in alkali-activated binders based on slag, fly ash, effects of accelerated carbonation. Cement, Concrete Research, 53 (2013), pp. 127-144, https://doi.org/10.1016/j. cemconres.2013.06.007

[30] Van Jaarsveld, J.G.S., van Deventer, J.S.J., Lukey, G.C.: The characterisation of source materials in fly ash-based geopolymers, Materials Letters, 57 (2003), pp. 1272-1280, https:// doi.org/10.1016/S0167-577X(02)00971-0 